\title{
EFEKTIFITAS HUKUM PELAKSAAN PERATURAN DAERAH KOTA PALOPO NOMOR 8 TAHUN 2013 TENTANG PENYELENGGARAAN ADMINISTRASI KEPENDUDUKAN (Studi Hak Anak Memperoleh Akta Kelahiran)
}

\author{
Laola Subair \\ Universitas Andi Djemma Palopo
}

\begin{abstract}
This study aims to determine the effectiveness of the implementation of the Regional Regulation of Palopo City Number 8 of 2013 concerning the administration of population administration to obtain birth certificates and to find out the inhibiting factors for obtaining birth certificates for children based on Palopo City Regulation Number 8 of 2013 concerning Implementation of Population Administration.

The research method used in the discussion of this paper, the author uses an empirical normative approach, the source of writing data obtained from documents and legislation with the type of data in the form of primary and secondary data, informants taken by the author is the Office of Population. Qualitative data analysis.

Based on the results of the study, namely: First: Based on the data compiled by the authors from 2015-2017 it turns out that many children do not have birth certificates in Palopo City. This shows that the Regional Regulation of Palopo City Number 8 of 2013 concerning the Implementation of Population Administration is not effective even though there have been concrete actions taken by the Palopo City Population and Civil Registration Service. Second: inhibiting factors from government administrators (implementing apparatus) among them are implementing officers who carry out discriminatory actions and uneven socialization. The inhibiting factors that come from the community are lack of public awareness about the importance of ownership of population documents in this case the birth certificate and incomplete files submitted by the community when arranging the birth certificate.
\end{abstract}

Keywords: Effectiveness of Law, Regional Regulations, Population Administration

\section{A. PENDAHULUAN}

Anak yang lahir tidak hanya sebagai rahmat bagi kedua orang tuanya saja, tetapi juga sebagai amanah yang diperoleh dari Tuhan Yang Maha Esa. Dikatakan rahmat, sebab anak merupakan pemberian Tuhan Yang Maha Esa, semua orangtua berharap untuk mendapatkannya sekalipun dengan cara yang membutuhkan usaha yang besar. Sebagai amanah, berarti ada kewajiban semua pihak untuk memberikan perlindungan pada anak. Baik pemerintah, 
masyarakat dan khususnya orangtua sebagai orang yang paling dekat dengan anak, memiliki tugas dan kewajiban melindungi anak agar dapat berkembang secara optimal.

Seorang anak berhak memperoleh perlakuan yang adil dan terhindar dari segala ancaman yang dapat merugikan dirinya karena anak merupakan anugerah Allah SWT yang merupakan amanah, titipan yang paling berharga yang harus dijaga, dirawat dan dididik dengan baik oleh para orang tua. Anak menurut kamus besar bahasa Indonesia adalah keturunan yang kedua. ${ }^{1}$ Seorang anak memerlukan perlindungan fisik, mental dan sosial secara utuh, serasi, selaras dan seimbang. Hal ini disebabkan karena anak merupakan generasi penerus cita-cita bangsa. Sebagai generasi penerus cita-cita bangsa, orang tua harus memperlakukan anak dengan baik mulai dari dalam kandungan, balita (bayi usia lima tahun), anak usia sekolah (remaja) sampai anak tersebut dewasa.

Keberadaan anak dalam keluarga merupakan suatu hal yang sangat berarti. Anak memiliki arti yang berbeda-beda bagi setiap orang. Anak adalah amanah yang harus dipertanggungjawabkan orang tua kepada Allah SWT. Anak adalah tempat orang tua mencurahkan kasih sayangnya. Dan anak juga penyambung keturunan, sebagai investasi masa depan, dan anak merupakan harapan untuk menjadi sandaran dikala usia lanjut. Ia dianggap sebagai modal untuk meningkatkan peringkat hidup sehingga dapat mengontrol status sosial orang tua. Oleh sebab itu orang tua harus memelihara, membesarkan, merawat, menyantuni, dan mendidik anak-anaknya dengan penuh tanggung jawab dan kasih sayang. ${ }^{2}$

Undang-undang Nomor 4 Tahun 1979 Tentang Kesejahteraan anak (UU Kesejahteraan Anak) Pasal 2 seorang anak berhak atas pemeliharaan dan perlindungan sejak anak berada dalam kandungan ibunya, serta perlindungan terhadap lingkungan hidup yang membahayakan atau menghambat bagi pertumbuhannya dengan wajar. ${ }^{3}$

Anak sebagai penerus keluarga dan cikal bakal menjadi pemimpin dalam masyarakat dan negara, sejak dilahirkan harus memiliki identitas hukum yang jelas, sehingga tidak menjadi hambatan kultural, sosial, politik, dan hukum bagi perkembangannya dimasa mendatang. Selain itu, hukum ingin memastikan bahwa anak yang dilahirkan dari rahim seorang ibu adalah sah, dan secara sosiologis tidak menjadi pergunjingan dalam masyarakat dengan memberi label anak haram, anak tidak sah, anak zinah, dan sebagainya yang pada gilirannya dapat mempengaruhi psikologi anak tersebut. ${ }^{4}$ Sebagai subjek

1 Departemen Pendidikan Nasional, Kamus Besar Bahasa Indonesia (Cet. 3. Jakarta: Balai Pustaka, 2005), h.41

2 Yunahar Ilyas, Kuliah Akhlak, (Yogyakarta: LPPI Universitas Muhammadiyah Yogyakarta, 2007), h. 172

${ }^{3}$ Undang-Undang Nomor 4 Tahun 1979 tentang Kesejahteraan Anak, Pasal 2

${ }^{4}$ Tan Kamello, dkk, Hukum Perdata Hukum Orang dan Keluarga, (Medan: USU Press, 2011), h. 
hukum, manusia menyandang hak dan kewajiban. Pengakuan terhadap manusia pribadi sebagai subjek hukum (rechtspersoonlijkheid). ${ }^{5}$

Anak yang telah dilahirkan, maka hak atas hidup dan hak merdeka sebagai hak dasar dan kebebasan dasar tidak dapat dilenyapkan atau dihilangkan, tetapi harus dilindungi dan diperluas hak atas hidup dan hak merdeka tersebut. Hak asasi anak tersebut merupakan bagian dari hak asasi manusia yang mendapat jaminan dan perlindungan hukum baik Hukum Nasional seperti yang termuat dalam Undang-Undang Dasar 1945, UndangUndang Nomor 39 Tahun 1999 tentang Hak Asasi Manusia telah mencantumkan tentang hak anak, pelaksanaan kewajiban dan tanggung jawab orang tua, keluarga, masyarakat, pemerintah dan negara untuk memberikan perlindungan pada anak.

Untuk keberlangsungan hidup manusia yang selanjutnya diperlukan suatu pembangunan pada generasi-genarasi yang baru yang nantinya akan menggantikan generasi yang sudah tua sehingga proses kehidupan terus berjalan tanpa henti. Oleh sebab itu, diperlukan kerjasama bagi semua pihak untuk melakukan hal tersebut terutama pemerintah selaku penyelenggara negara dan yang paling bertanggung jawab untuk memberikan jaminan perlindungan terhadap hak-hak setiap individu yang baru lahir (anak) demi masa depan mareka sendiri yang nantinya akan menjadi generasi-generasi yang sesuai diharapkan oleh bangsa dan negara.

Selain menjadi penerus keberlangsungan hidup ummat manusia, anak juga merupakan aset yang berharga untuk melanjutkan pembangunan bagi bangsa dan negara, dimana anak (subyek hukum) tersebut mempunyai hak dan kewajiban yang dilindungi oleh hukum. Undang-Undang Nomor 23 Tahun 2002 Tentang Perlindungan Anak pasal 21 menerangkan bahwa:6

"Negara dan pemerintah berkewajiban dan bertanggung jawab menghormati dan menjamin hak asasi setiap anak tanpa membedakan suku, agama, ras, golongan, jenis kelamin, etnik, budaya dan bahasa, status hukum anak, urutan kelahiran anak, dan kondisi fisik dan/atau mental"

Salah satu pemberian jaminan terhadap status hukum seorang anak yaitu dengan memiliki akta kelahiran yang menjadi bukti legal terhadap dirinya dan keluarganya. Menurut Undang-undang Nomor 23 Tahun 2002 tentang Perlindungan Anak Pasal 27 menerangkan bahwa: ${ }^{7}$

(1) Identitas diri setiap anak harus diberikan sejak kelahirannya.

(2) Identitas sebagaimana dimaksud dalam ayat (1) dituangkan dalam akta kelahiran.

(3) Pembuatan akta kelahiran didasarkan pada surat keterangan dari orang yang menyaksikan dan/atau membantu proses kelahiran.

${ }^{5}$ Riduan Syahrani, Seluk Beluk dan Asas-Asas Hukum Perdata, (Bandung: PT. Alumni, 1993), h.

\footnotetext{
${ }^{6}$ Undang-Undang Nomor 23 Tahun 2002 tentang Perlindungan Anak, Pasal 21

${ }^{7}$ Undang-Undang Nomor 23 Tahun 2002 tentang Perlindungan Anak, Pasal 27
} 
(4) Dalam hal anak yang proses kelahirannya tidak diketahui, dan orang tuanya tidak diketahui keberadaannya, pembuatan akta kelahiran untuk anak tersebut didasarkan pada keterangan orang yang menemukannya.

Hal tersebut sangat sesuai dengan Undang-undang Nomor 23 Tahun 2006 tentang Administarsi Kependudukan, Pasal 27 yang menerangkan bahwa:8

(1) Setiap kelahiran wajib dilaporkan oleh Penduduk kepada Instansi Pelaksana di tempat terjadinya peristiwa kelahiran paling lambat 60 (enam puluh) hari sejak kelahiran.

(2) Berdasarkan laporan sebagaimana dimaksud pada ayat (1), Pejabat Pencatatan Sipil mencatat pada Register Akta Kelahiran dan menerbitkan Kutipan Akta Kelahiran.

Pencatatan kelahiran yang tercantum dalam akta sangat penting baik untuk diri sendiri maupun orang lain oleh karena dengan pencatatan ini siapapun dapat dengan mudah memperoleh kepastian akan kejadian-kejadian ${ }^{9}$. Termasuk agar terhindar dari diskriminasi.

Akta kelahiran anak, bertujuan untuk mewujudkan kepastian hukum bagi seseorang anak, karena: a) Pencatatan kelahiran anak memastikan secara tegas tentang adanya pengakuan negara terhadap keberadan anak sebagai subjek hukum. Ini berarti bahwa pencatatan kelahiran tersebut, menjelaskan identitas yuridis seorang anak karena memuat nama anak, nama kedua orang tuanya, tempat dan tanggal lahir, yang diakui/disahkan oleh pejabat yang berwenang untuk itu (pejabat/pegawai kantor cacatan sipil/Dinas Kependudukan). b) Pencatatan kelahiran anak memastikan perlindungan hukum atas hak-hak seseorang (anak) ini berarti bahwa pencatatan kelahiran anak memberi dasar hukum bagi pemerintah dalam memberi perlindungan hak-hak anak. ${ }^{10}$

Akta kelahiran merupakan sebuah dokumen yang pertama dimiliki oleh seorang anak. Dengan memiliki akta kelahiran tersebut maka secara otomatis negara mengakui status seorang anak tersebut sebagai warga negaranya secara de jure. Dewasa ini, asumsi yang terbangun dalam masyarakat bahwa anak yang baru lahir cukup memiliki surat keterangan lahir saja, padahal jika dilihat lebih jauh lagi akta kelahiran dengan surat keterangan lahir tidaklah sama. Surat kenal lahir maupun surat keterangan lahir tidaklah berhak mempergunakan predikat akta, tetapi hanya sekedar keterangan biasa.

Secara yuridis seorang anak yang tidak memiliki akta kelahiran maka anak tersebut tidak mendapatkan perlindungan hukum yang pasti. Begitu sangat pentingnya sebuah akta kelahiran untuk dimiliki, maka pemerintah selaku penyelenggara negara harus memberikan jaminan kepada setiap anak yang merupakan Warga Negara Indonesia baik dipandang secara ius soli

\footnotetext{
${ }^{8}$ Undang-undang Nomor 23 Tahun 2006 tentang Administarsi Kependudukan, Pasal 27

${ }^{9}$ R. Soetojo Prawirohamidjojo dan Marthalena Pohan, Hukum Orang dan Keluarga (Personen en Familie Recht), (Surabaya: Airlangga University Press, 2000), h.6

${ }^{10}$ Maidin Gultom, Perlindungan Hukum terhadap Anak dan Perempuan, (Bandung: PT. Refika Aditama, 2012), h.117
} 
(berada di Indonesia) maupun secara ius sanguinis (keturunan warga negara Indonesia) harus memiliki identitas diri berupa akta kelahiran. Pengurusan akta kelahiran menjadi kewajiban pemerintah, bukan masyarakat yang meminta. Jadi seharusnya, begitu anak lahir dan orang tuanya melapor akan langsung mendapatkan akta kelahiran yang tentunya harus sesuai dengan prosedur yang telah ditetapkan oleh Pemerintah.

Di Kota Palopo sendiri, berdasarkan data dari Dinas Kependudukan dan Pencatatan Sipil tahun 2017 tercatat 28.181 anak yang belum memiliki akta kelahiran. ${ }^{11} \mathrm{Hal}$ ini tentu merugikan anak sebagai warga Negara.

Di Kota Palopo sendiri terdapat Peraturan Daerah (Perda) Nomor 8 Tahun 2013 tentang Penyelenggaraan Administrasi Kependudukan. Dalam perda tersebut menerangkan bahwa, Administrasi kependudukan adalah rangkaian kegiatan penataan dan penertiban dalam penerbitan dokumen dan data kependudukan melalui pendaftaran penduduk, pencatatan sipil, pengelolaan informasi administrasi kependudukan serta pendayagunaan hasilnya untuk pelayanan publik dan pembangunan sektor lain (Pasal 1) dan salah satu bentuk pencatatan sipil yaitu akta kelahiran.

Berdasarkan data diatas ternyata banyak masyarakat yang tidak mematuhi Perda tersebut yang sebenarnya hal tersebut baik untuk dirinya sendiri karena menyangkut haknya sebagai manusia. Ini membuktikan bahwa Perda tersebut tidak berjalan efektif dimasyarakat. Membicarakan tentang efektivitas hukum berarti membicarakan daya kerja hukum itu dalam mengatur dan atau memaksa masyarakat untuk taat terhadap hukum. Hukum dapat efektif jikalau faktor-faktor yang mempengaruhi hukum tersebut dapat berfungsi dengan sebaik-baiknya. Ukuran efektif atau tidaknya suatu peraturan perundang-undangan yang berlaku dapat dilihat dari perilaku masyarakat. Suatu hukum atau peraturan perundang-undangan akan efektif apabila warga masyarakat berperilaku sesuai dengan yang diharapkan atau dikehendaki oleh atau peraturan perundang-undangan tersebut mencapai tujuan yang dikehendaki, maka efektivitas hukum atau peraturan perundangundangan tersebut telah dicapai.

Dalam rangka pembinaan dan tertib administrasi kependudukan terhadap pelayanan penyelenggaraan dibidang pendaftaran penduduk dan penerbitan Akta Catatan Sipil, Pemerintah Kota Palopo mengeluarkan Peraturan Perda Nomor 8 Tahun 2013 tentang Penyelenggaraan Administrasi Kependudukan. Adapun ketentuan mengajukan permohonan pencatatan akta kelahiran diatur dalam Pasal 35 sebagai berikut :

(1) Setiap kelahiran di Daerah wajib dilaporkan paling lambat 60 (enam puluh) hari kerja sejak tanggal kelahiran kepada Dinas.

(2) Setiap pelaporan kelahiran sebgaimana dimaksud pada ayat (1) dicatat pada register akta kelahiran dan diterbitkan kutipan akta kelahiran.

(3) Pencatatan kelahiran yang melampaui batas waktu sebagaimana dimaksud pada ayat (1) sampai dengan 1 (satu) tahun dilaksanakan setelah

${ }^{11}$ Dinas Kependudukan dan Pencatatan Sipil Kota Palopo 
mendapatkan persetujuan Kepala Dinas.

Selanjutnya Perda tersebut digunakan sebagai dasar untuk melakukan proses administrasi yang berkaitan dengan pencatatan sipil dalam hal ini adalah penerbitan akta kelahiran yang ada di Kota Palopo. Atas dasar pemikiran dan permasalahan tersebut maka penulis merasa tertarik untuk membahas permasalahan tersebut.

Adapun tujuan yang hendak ingin dicapai dalam penelitian tersebut sebagai berikut:

1. Untuk mengetahui efektivitas pelaksanaan peraturan Daerah Kota Palopo Nomor 8 Tahun 2013 tentang penyelenggaraan administrasi kependudukan untuk memperoleh akta kelahiran.

2. Untuk mengetahui faktor penghambat yang timbul untuk memperoleh akta kelahiran bagi anak berdasarkan Peraturan Daerah Kota Palopo Nomor 8 tahun 2013 tentang Penyelenggaraan Administrasi Kependudukan

\section{B. METODE PENELITIAN}

\section{Tipe Penelitian}

Tipe penelitian yang digunakan dalam penelitian ini adalah normatif empiris. Pada dasarnya jenis penelitian ini merupakan penggabungan antara pendekatan hukum normatif dengan adanya penambahan berbagai unsur empiris. Jenis penelitian nomatif empiris mengenai implementasi ketentuan hukum normatif (undang-undang) dalam aksinya pada setiap peristiwa hukum tertentu yang terjadi didalam masyarakat. Dalam penelitian ini peneliti menggukan metode field research (penelitian lapangan) untuk mendapatkan data yang berkaitan dengan Dinas Kependudukan dan Pencatatan Sipil Kota Palopo, keefektivitasan pelaksanaan Peraturan Daerah tersebut dan faktor yang menjadi penghambat untuk memperoleh akta kelahiran.

\section{Lokasi Penelitian}

Lokasi penelitian ini berlokasikan di Kantor Dinas Kependudukan dan Pencatatan Sipil Kota Palopo dengan pertimbangan bahwa Dinas tersebut merupakan instansi yang memiliki kewenangan untuk mengurusi masalah kependudukan dan berwenang mengeluarkan akta catatan sipil serta informasi yang dibutuhkan peneliti sangat relevan dengan pokok permasalahan yang menjadi objek penelitian.

\section{Jenis dan Sumber Data}

Jenis dan sumber data yang digunakan oleh peneliti pada penelitian ini yaitu sebagai berikut:

\section{a. Sumber Data Primer}

Sumber data primer, adapun yang akan menjadi sumber data primer dalam penelitian ini adalah Dinas Kependudukan dan Catatan Sipil Kota Palopo. 


\section{b. Sumber Data Sekunder}

1) Bahan Hukum Primer

Bahan hukum primer yaitu materi hukum yang memiliki status yang mengikat secara yuridis, yakni dapat berupa norma atau kaidah dasar, peraturan perundang-undangan, dan lain sebagainya. Dalam hal ini yang menjadi bahan hukum primer sebagai berikut:

a. Undang-Undang Nomor 39 Tahun 1999 tentang Hak Asasi Manusia

b. Undang-Undang Nomor 23 tahun 2002 tentang Perlindungan Anak

c. Undang-Undang Nomor 4 Tahun 1979 tentang Kesejahteraan Anak

d. Undang-Undang Nomor 23 Tahun 2006 tentang Administrasi Kependudukan

e. Peraturan Daerah Kota Palopo Nomor 8 Tahun 2013 tentang Penyelenggaraan Administrasi Kependudukan

\section{2) Bahan Hukum Sekunder}

Yakni berupa hasil karya yang berasal dari kalangan hukum, hasil penelitian, artikel hingga internet serta bahan lainnya yang memiliki relevansi dengan pembahasan yang diangkat oleh peneliti.

\section{Teknik Pengumpulan Data}

Penggunaan metode pengumpulan data yang dilakukan oleh penulis yaitu dengan cara terjun secara langsung ke lapangan untuk mendapatkan data yang autentik. Hal ini dilakukan untuk menghindari kesalahan atau kekeliruan dalam hasil penelitian yang akan dilaksanakan nantinya. Adapun metode pengumpulan data yang dilakukan dalam penelitian ini adalah metode observasi yang merupakan kegiatan sehari-hari manusia dengan menggunakan pancaindra mata sebagai alat bantu utamanya selain panca indra lainya seperti telinga, penciuman, mulut dan kulit ${ }^{12}$. Metode wawancara merupakan proses memperoleh keterangan untuk tujuan penulisan dengan cara tanya jawab sambil bertatap muka antara pewawancara dengan informan atau orang yang di wawancarai, dengan atau tampa menggunakan pedoman wawancara, dimana pewawancara dan informan terlibat dalam kehidupan sosial yang cukup lama ${ }^{13}$ guna menggali informasi mengenai pokok permasalahan yang terjadi di lapangan. Dan metode dokumentasi yaitu pengumpulan data-data dan bahan-bahan berupa dokumen. ${ }^{14}$ Dalam hal ini berupa buku, surat kabar, majalah, jurnal, karya tulis ilmiah, dokumen yang berupa peraturan Pemerintah serta Undang-Undang. Metode ini dipergunakan dalam rangka mencari referensi tambahan dan menguatkan hasil kajian yang mendalam pada penelitian ini.

12 Burhan Bungin, Metodologi Penulisan Kualitatif (Jakarta: Kencana, 2009), h. 115

${ }^{13}$ Burhan Bungin, Metodologi Penulisan Kualitatif, h. 108

${ }^{14}$ Soerjono Soekanto, Pengantar Penelitian Hukum, (Cet. 3, Jakarta: PT Universitas Indonesia, 2010), h. 66 


\section{Teknik Analisis Data}

Analisis data merupakan suatu proses penyederhanaan data yang mudah dibaca dan diinterprestasikan. Analisa data dilakukan sejak awal penelitian hingga penelitian selesai. Untuk menganalisa data yang akan dikumpulkan dalam penelitian ini, maka digunakan teknik analisa kualitatif, dengan metode yaitu deskriptif. Analisis ini juga dimaksudkan agar kasus-kasus yang terjadi di lokasi penelitian dapat dikaji lebih mendalam dan fenomena yang ada dapat digambarkan secara lebih terperinci.

Data yang sudah didapat selanjutnya diedit ulang dan dilihat kelengkapannya dan diselingi dengan klasifikasi data untuk memperoleh sistematika pembahasan dan terdeskripsikan dengan rapi. Menurut Soedjono dan Addurrahman, analisis ini adalah suatu teknik yang digunakan untuk menarik kesimpulan melalui usaha menemukan karakteristik pesan yang dilakukan secara obyektif dan sistematis. ${ }^{15}$ Analisis ini dimaksudkan melakukan analisis terhadap makna yang terkandung dalam masalah yang hendak dibahas.

Dari kegiatan tersebut merupakan kegiatan yang saling berkaitan pada saat sebelumnya, selama maupun sesudah pengumpulan data dalam bentuk yang sejajar untuk membangun wawasan umum disebut analisis menurut Miles dan Haberman. ${ }^{16}$

\section{1) Reduksi Data}

Mereduksi data berarti merangkum, memilih hal-hal yang pokok, memfokuskan pada hal-hal yang penting, dicari tema dan polanya. Dengan demikian data yang telah direduksi akan memberikan gambaran yang lebih jelas, dan mempermudah peneliti untuk melakukan pengumpulan data selanjutnya, dan mencarinya bila diperlukan. Reduksi data dapat dibantu dengan peralatan elektronik seperti komputer mini, dengan memberikan kode pada aspek-aspek tertentu. ${ }^{17}$

Reduksi data juga merupakan suatu proses analisis data yang mempermudah peneliti untuk menarik sebuah kesimpulan dengan merangkum, memilih hal-hal pokok yang sedang dianalisis.

\section{2) Display Data (Penyajian Data)}

Setelah direduksi, maka langkah selanjutnya adalah mendisplay data. Dalam penelitian kualitatif, penyajian data bisa dilakukan dalam uraian singkat, bagan, hubungan antar kartegori, flowchart, dan sejenisnya. Dalam hal ini Miles dan Huberman (1984) menyatakan, yang paling sering digunakan untuk menyajikan data dalam penelitian kualitatif adalah dengan teks yang bersifat naratif. Dengan mendisplay data, maka akan memudahkan untuk

\footnotetext{
15 Soerjono, dan Abdurrahman, Bentuk Penelitian Suatu Pemikiran dan Penerapan, (Jakarta: Rineka Cipta, 1991), h. 13

16 Muhammad Idrus, Metode Penelitian Ilmu Sosial Pendekatan Kualitatif dan Kuantitatif, (Jakarta: Erlangga, 2011), h. 148

${ }^{17}$ Sugiyono, Metode Penelitian Kuantitatif, Kualitatif dan R\&D, (Bandung: CV. Alfabeta, 2009), h. 247
} 
memahami apa yang terjadi, merencanakan kerja selanjutnya berdasarkan apa yang telah difahami tersebut. ${ }^{18}$

\section{3) Conclusion Drawing/Verification}

Langkah ketiga dalam analisis data kualitatif menurut Miles dan Huberman adalah penarikan kesimpulan dan verifikasi. Kesimpulan awal yang dikemukakan masih bersifat sementara, dan akan berubah bila tidak ditemukan bukti-bukti yang kuat yang mendukung pada tahap pengumpulan data berikutnya. Tetapi apabila kesimpulan yang dikemukakan pada tahap awal, didukung oleh bukti-bukti yang valid dan konsisten saat peneliti kembali ke lapangan pengumpulan data, maka kesimpulan yang dikemukakan merupakan kesimpulan yang kredibel. ${ }^{19}$

\section{HASIL PENELITIAN DAN PEMBAHASAN}

Efektivitas Pelaksanaan Peraturan Daerah Kota Palopo Nomor 8 Tahun 2013 Tentang Penyelenggaraan Administrasi Kependudukan Untuk Memperoleh Akta Kelahiran

Efektivitas hukum merupakan keberhasilan hukum untuk mencapai tujuannya. Efektivitas diartikan sebagai sesuatu atau kondisi di mana telah sesuai dengan target atau tujuan yang akan ditempuh atau diharapkan. Hukum itu dikatakan efektif apabila warga masyarakat berperilaku sesuai yang diharapkan atau dikehendaki oleh hukum.

Efektivitas penerapan hukum dalam masyarakat ditentukan oleh daya kerja hukum itu sendiri dalam mengatur dan memaksa masyarakat. Kesadaran hukum dan ketaatan hukum merupakan dua hal yang sangat menentukan efektif atau tidaknya pelaksanaan perundang-undangan atau aturan hukum dalam masyarakat.

Menurut Soerjono Soekanto, suatu hukum dapat dikataka efektif apabila:20

1. Dapat mencapai tujuan yang telah dikehendaki, terutama pembentuk hukum serta pelaksana.

2. Hukum efektif apabila di dalam masyarakat, warganya berperilaku sesuai dengan apa yang telah dikehendaki oleh hukum.

Efektivitas hukum menyoroti tentang bagaimana suatu peraturan yang dibentuk untuk mencapai tujuan yang diinginkan, sehingga untuk mengukur efektivitas dari suatu peraturan dilihat dari keberhasilan pencapaian tujuan yang diinginkan. Jika peraturan tersebut telah mencapai tujuannya, maka peraturan tersebut dapat dikatakan efektif, begitu pula sebaliknya.

Guna mencapai tujuan tersebut maka perlu diperhatikan beberapa hal sebagai berikut, rumusan peraturan perundang-undangan harus diterima oleh masyarakat, menjadi tujuan bersama masyarakat yaitu cita-cita kebenaran, cita-

${ }^{18}$ Sugiyono, Metode Penelitian Kuantitatif, Kualitatif dan $R \& D$, h. 249

${ }^{19}$ Sugiyono, Metode Penelitian Kuantitatif, Kualitatif dan R\&D, h. 252

20 Soerjono Soekanto, Pokok-Pokok Sosiologi Hukum, (Jakarta: Raja Grafindo Persada, 2007), 
cita keadilan, dan cita-cita kesusilaan. Peraturan daerah juga harus sesuai dengan suatu paham atau kesadaran hukum masyarakat, harus sesuai dengan hukum yang hidup di masyarakat, serta harus mempunyai dasar atau tujuan pembentukan yang telah diatur sebelumnya dan atau ditetapkan pada peraturan yang lebih tinggi kewenangan berlakunya.

Untuk mengetahui sejauh mana efektivitas hukum atau aturan maka yang harus diketahui adalah sejauh mana hukum atau aturan itu ditaati atau tidak ditaati oleh masyarakat. Dalam peraturan Daerah kota Palopo Nomor 8 Tahun 2013 Tentang Penyelenggaraan Administrasi Kependudukan pasal 2 menerangkan bahwa:

"Setiap penduduk, penduduk non permanen dan penduduk sementara, mempunyai hak untuk memperoleh:

a. Dokumen kependudukan;

b. Pelayanan yang sama dalam pendaftaran penduduk dan pencatatan sipil;

c. Perlindungan atas data pribadi;

d. Kepastian hukum atas kepemilikan dokumen kependudukan;

e. Informasi mengenai data hasil pendaftaran penduduk dan pencatatan sipil atas dirinya dan/atau keluarganya; dan

f. Pemulihan nama baik sebagai akibat kesalahan dalam pendaftaran penduduk dan pencatatan sipil serta penyalahgunaan data pribadi oleh Instansi Pelaksana"

Berdasarkan Perda yang berlaku semestinya setiap penduduk mempunyai hak untuk memperoleh dokumen kependudukan. Data yang diperoleh peneliti dari Dinas Kependudukan dan Pencatatan Sipil Kota Palopo, dari tahun 2015 hingga 2017 ternyata masih banyak anak yang belum memiliki akta kelahiran di Kota Palopo. Hal ini menunjukkan peraturan Daerah Kota Palopo Nomor 8 Tahun 2013 Tentang Penyelenggaraan Administrasi Kependudukan tidak berjalan efektif sekalipun sudah ada aksi nyata yang dilakukan oleh Dinas Kependudukan Kota Palopo. Seperti yang disampaikan oleh Ibu Tenriawati,SH selaku sekertaris Dinas Kependudukan Kota Palopo, bahwa Dinas Kependudukan dan Pencatatan Sipil Kota Palopo telah melakukan upaya perihal pentingnya memiliki akta kelahiran bagi anak. Dinas Kependudukan melakukan upaya tersebut dalam bentuk sosialisasi, penyuluhan, kemudian membuat brosur, dan juga membuat pengumuman. Dinas Kependudukan melakukan semua itu secara langsung disetiap Kecamatan yang ada di Kota Palopo. ${ }^{21}$

Seperti yang disampaikan oleh Ibu Tenriawati,SH selaku sekertaris Dinas Kependudukan Kota Palopo tentu para aparatur telah melaksanakan tugasnya dalam berbagai bentuk apapun. Tetapi pada kenyataanya yang terjadi di masyarakat tidak sesuai dengan apa yang di harapakan, Hanya saja sekalipun telah melakukan aksi nyata tetapi tidak efektif maka hal tersebut akan menjadi

21 Wawancara Bersama Sekertaris Dinas Kependudukan Kota Palopo Ibu Tenriawati,SH (2 Februari 2018) 
sia-sia. Bukti bahwa masih kurangnya partisipasi masyarakat terhadap aksi nyata yang dilakukan oleh aparatur Dinas Kependudukan dan Pencatatan Sipil Kota Palopo yaitu masih kurangnya kesadaran masyarakat akan pentingnya dokumen kependudukan, dalam hal ini adalah akta kelahiran. Berdasarkan data yang telah diperoleh peneliti di Kantor Dinas Kependudukan dan Pencatatan sipil Kota Palopo menunjukkan bahwa dari tahun 2015 hingga tahun 2017 masih banyak anak di Kota Palopo yang belum memiliki akta Kelahiran sebagaimana yang dapat dilihat sebagai berikut:

Tabel 3:

Jumlah Anak Yang Tidak Memiliki Akta Kelahiran

Di Kota Palopo 2015-2017

\begin{tabular}{|c|c|c|c|c|c|c|}
\hline \multirow{4}{*}{} & \multicolumn{9}{|c|}{ Tahun } \\
\cline { 2 - 7 } & \multicolumn{2}{|c|}{$\mathbf{2 0 1 5}$} & \multicolumn{2}{c|}{$\mathbf{2 0 1 6}$} & \multicolumn{2}{c|}{$\mathbf{2 0 1 7}$} \\
\cline { 2 - 7 } & $\mathbf{L}$ & $\mathbf{P}$ & $\mathbf{L}$ & $\mathbf{P}$ & $\mathbf{L}$ & $\mathbf{P}$ \\
\cline { 2 - 7 } & 15.900 & 14.810 & 14.053 & 13.166 & 14.508 & 13.673 \\
\hline Jumlah & \multicolumn{2}{|c|}{30.710} & \multicolumn{2}{|c|}{27.219} & \multicolumn{2}{c|}{28.181} \\
\hline
\end{tabular}

Ket : L $=$ Laki-laki

$\mathrm{P}=$ Perempuan

Sumber: Dinas Kependudukan dan Pencatatan Sipil Kota Palopo

Berdasarkan data tersebut dengan tidak adanya kepemilikan akta kelahiran bagi anak tentu akan merugikan haknya untuk memperoleh perlindungan hukum. Akta kelahiran merupakan sebuah dokumen yang pertama dimiliki oleh seorang anak. Padahal dalam Peraturan Daerah No. 8 Tahun 2013 Tentang Penyelenggaraan Administrasi Kependudukan Pasal 35:

(1) Setiap kelahiran di Daerah wajib dilaporkan paling lambat 60 (enam puluh) hari kerja sejak tanggal kelahiran kepada Dinas.

(2) Setiap pelaporan kelahiran sebgaimana dimaksud pada ayat (1) dicatat pada register akta kelahiran dan diterbitkan kutipan akta kelahiran.

(3) Pencatatan kelahiran yang melampaui batas waktu sebagaimana dimaksud pada ayat (1) sampai dengan 1 (satu) tahun dilaksanakan setelah mendapatkan persetujuan Kepala Dinas.

Tentu hal itu bertentangan dengan Peraturan Daerah Kota Palopo No. 8 Tahun 2013 Tentang Penyelenggaraan Administrasi Kependudukan yang berlaku di Kota Palopo. Faktanya yang penulis temukan dilapangan bahwa kepemilikan dokumen kependudukan oleh setiap masyarakat di Kota Palopo dalam hal ini akta kelahiran bagi anak berdasarkan data dinas kependudukan dan pencatatan sipil Kota Palopo tahun 2017 sebanyak 28.181 anak yang belum memiliki akta kelahiran. Tentu hal ini tidaklah sesuai dengan Peraturan Daerah No. 8 Tahun 2013 Tentang Penyelenggaraan Administrasi Kependudukan yang berlaku.

Padahal dengan memiliki akta kelahiran maka secara otomatis negara mengakui status seorang anak tersebut sebagai warga negaranya secara de jure. Dewasa ini, asumsi yang terbangun dalam masyarakat bahwa anak yang baru 
lahir cukup memiliki surat keterangan lahir saja, padahal jika dilihat lebih jauh lagi akta kelahiran dengan surat keterangan lahir tidaklah sama. Akta kelahiran anak, bertujuan untuk mewujudkan kepastian hukum bagi seseorang anak, karena: a) Pencatatan kelahiran anak memastikan secara tegas tentang adanya pengakuan negara terhadap keberadan anak sebagai subjek hukum. Ini berarti bahwa pencatatan kelahiran tersebut, menjelaskan identitas yuridis seorang anak karena memuat nama anak, nama kedua orang tuanya, tempat dan tanggal lahir, yang diakui/disahkan oleh pejabat yang berwenang untuk itu (pejabat/pegawai kantor cacatan sipil/Dinas Kependudukan). b) Pencatatan kelahiran anak memastikan perlindungan hukum atas hak-hak seseorang (anak) ini berarti bahwa pencatatan kelahiran anak memberi dasar hukum bagi pemerintah dalam memberi perlindungan hak-hak anak. ${ }^{22}$

Jika kita mau mengacu pada peraturan Daerah Nomor 8 Tahun 2013 tentang Penyelenggaraan Administrasi Kependudukan sebenarnya syarat untuk pengajuan kepemilikan dokumen akta kelahiran untuk anak sangatlah mudah. Adapun standar pelayanan minimal Dinas Kependudukan dan Pecatatan Sipil Kota Palopo sebagai berikut:

Pencatatan peristiwa kelahiran sebagaimana dimaksud pada ayat (1), dilakukan dengan memperhatikan klasifikasi sebagai berikut :

a. Kelahiran Penduduk WNI di daerah;

b. Kelahiran Penduduk Non Permanen di daerah;

c. Kelahiran Penduduk Orang Asing di daerah;

d. Kelahiran Penduduk Sementara di daerah;

e. Kelahiran Orang Asing pemegang visa Kunjungan di daerah; dan

f. Kelahiran anak yang tidak diketahui asal usulnya atau keberadaan orang tuanya di daerah.

Persyaratan pencatatan kelahiran penduduk WNI di daerah :

a. Surat Keterangan Kelahiran dari Kelurahan;

b. Asli dan Fotokopi Surat Keterangan Kelahiran dari dokter/bidan/penolong kelahiran/Nakhoda Kapal Laut atau Pilot Pesawat Terbang dengan memperlihatkan aslinya;

c. Fotokopi Surat Nikah/ Akta Perkawinan orang tua;

d. Fotokopi KK dan KTP orang tua;

e. Nama dan identitas saksi pelaporan kelahiran;

f. Persetujuan Kepala Dinas dalam hal pelaporannya melebihi 60 (enam puluh) hari dan kurang dari 1 (satu) tahun sejak tanggal kelahirannya.

Faktor Penghambat Untuk Memperoleh Akta Kelahiran Bagi Anak Berdasarkan Peraturan Daerah Kota Palopo Nomor 8 Tahun 2013 tentang Penyelenggaraan Administrasi Kependudukan

Tujuan utama pelayanan publik ialah memberikan kesejahteraan bagi masyarakat sebagai penerima pelayanan yang diberikan oleh Pemerintah

${ }^{22}$ Maidin Gultom, Perlindungan Hukum terhadap Anak dan Perempuan, (Bandung: PT. Refika Aditama, 2012), h.117 
Daerah khususnya pada pelayanan Adminstrasi Kependudukan di Dinas Kependudukan dan Pencatatan Sipil Kota Palopo. Pada dasarnya pelayanan publik berbicara mengenai pemberi dan penerimaan layanan yang diberikan oleh Pemerintah, namun kemudian menjadi rumit tatkala menyangkut pada aspek penilaian tentang kualitas pelayanan yang diberikan oleh pemberi layanan dalam hal ini yang dimaksudkan adalah pelayanan publik terkait pengurusan identitas/dokumen kependudukan masyarakat oleh Satuan Kerja Perangkat Daerah (SKPD) di Kantor Dinas Kependudukan dan Catatan Sipil Kota Palopo. Oleh karena pemberi layanan dilakukan oleh Negara (pemerintah birokrasi/SKPD) maka dibutuhkan beberapa prasayarat penting yang harus dilalui oleh pemberi layanan, sebelum produk layanan diberikan kepada masyarakat.

Prasyarat tersebut pertama, adanya proses yang harus dilakukan oleh pemberi layanan agar betul-betul mampu menjawab kebutuhan masyarakat khususnya warga Kota Palopo untuk dapat memperoleh akta kelahiran dengan mudah dan efisien. Medianya bermacam-macam, misalnya melalui kesepakatan warga, musyawarah perencanaan pembangunan, dengar pendapat dan lain sebagainya. Kedua, adanya regulasi yang berbentuk produk hukum untuk menjamin adanya kepastian dalam pola relasi antara penerima layanan dengan pemberi layanan. Hal ini akan berdampak baik pada jalannya peraturan daerah tersebut dengan baik.

Dalam praktiknya pelayanan publik di Kantor Dinas Kependudukan dan Catatan Sipil Kota Palopo yang ada terkadang masih terjadi kasus seperti ketidakpastian waktu pelayanan kapan dokumen kependudukan yang diurus tersebut akan selesai, sehingga menimbulkan banyak keluhan dari masyarakat. Hal diatas dapat menjadi faktor yang dapat menghambat untuk memperoleh akta kelahiran di Kota Palopo. Berdasarkan fakta yang ditemukan peneliti di lapanga da beberapa faktor yang timbul sehingga terjadi hambatan dimasyarakat untuk memperoleh akta kelahiran bagi anak diantaranya adalah sebagai berikut:

\section{Faktor Penghambat dari Penyelenggara Pemerintahan (Aparatur Pelaksana )}

Penyelenggaraan pemerintahan yang baik merupakan isu yang paling mengemuka dalam pengelolaan administrasi publik pada era otonomi daerah dewasa ini. Tuntutan gencar yang dilakukan oleh masyarakat yang kepada pemerintah untuk melaksanakan penyelenggaraan pemerintahan yang baik adalah sejalan dengan meningkatnya tingkat pengetahuan masyarakat, disamping adanya pengaruh globalisasi.

Penyelenggara pemerintah dalam hal ini adalah aparatur pelaksana memiliki peran yang penting untuk memberikan pelayanan yang baik kepada masyarakat. Dalam kamus besar bahasa Indonesia, Aparatur dapat diartikan sebagai alat Negara atau pegawai Negeri yang bekerja di badan pemerintah. ${ }^{23}$ Selain itu, mengenai aparatur tersebut, adapun pengertian Aparatur adalah

${ }^{23}$ Departemen Pendidikan Dan Kebudayaan, Kamus Besar Bahasa Indonesia, (Cet. 3 Jakarta: Balai Pustaka, 2005), h. 17 
aspek administrasi yang diperlukan dalam penyelenggaraan pemerintahan/ Negara, sebagai alat unuk mencapai tujuan nasional. aspek-aspek administrasi itu terutama ialah kelembagaan (organisasi) dan kepegawaian. ${ }^{24}$ Adapun pengertian dari Pelaksana atau pelaksanaan adalah suatu kegiatan untuk merealisasikan rencana yang telah ditetapkan sebelumnya, sehingga tujuan dapat tercapai.

Suatu peraturan perundang yang baik terkadang tidak dapat ditegakkan secara baik, apabila yang menegakkan peraturan perundangan tersebut adalah aparatur penegak hukum yang tidak baik atau cakap. Dan hal tersebut dapat dipengaruhi oleh banyak hal, diantaranya rendahnya tingkat pemahaman dari aparatur penegak hukum terhadap substansi suatu peraturan perundangan.

Kelancaran penyelenggaraan administrasi kependudukan ini tergantung pada kinerja aparatur pelaksana oleh karena itu dalam mencapai tujuan pembangunan nasional yakni mewujudkan masyarakat madani yang taat hukum, berperadaban, modern, demokratis, makmur, adil dan bermoral tinggi, diperlukan seorang aparatur pelaksana yang bertugas sebagai abdi masyarakat yang harus menyelenggarakan pelayanan secara adil dan merata kepada masyaraka dengan dilandasi kesetiaan dan ketaatan kepada pancasila dan undang-undang dasar 1945.

Aparatur pelaksana khususnya dalam Penyelenggaraan Administrasi Kependudukan memiliki tugas dan Kewajiban yang meliputi, mendaftarkan peristiwa kependudukan masyarakat,memberikan pelayanan yang sama dan profesional, meneritbkan dokumen, mendokumentasikan hasil pendaftaran penduduk, menjamin keserasian dan keamanan data atas peristiwa penduduk, melakukan verifikasi dan validasi data informasi yang disampaikan oleh penduduk. Berdasarkan fakta yang peneliti temukan di lapangan Setidaknya ada dua faktor yang melatar belakangi hambatan untuk memperoleh akta kelahiran bagi anak yang berasal dari Aparatur Pelaksana yaitu, aparatur yang diskriminatif dan sosialisasi yang tidak merata.

\section{1) Aparatur Pelaksana Yang Diskriminatif dalam Memberikan Pelayanan}

Aparatur pelaksana atau biasa lebih dikenal sebagai Satuan Kerja Perangkat Daerah (SKPD) pada Dinas Kependudukan dan Catatan Sipil Kota Palopo, dalam memberikan pelayanan belumlah optimal secara merata dan menyeluruh. Dikarenakan dari hasil observasi yang dilakukan, peneliti menemukan bahwa masih ada sebagaian dari aparat pelaksana yang melakukan tindakan diskriminatif kepada masyarakat dalam pengurusan dokumen kependudukannya sehingga banyak masyarakat yang mengeluhkan hal tersebut.

Dalam peraturan Daerah kota Palopo Nomor 8 Tahun 2013 Tentang Penyelenggaraan Administrasi Kependudukan pasal 2 menerangkan bahwa:

"Setiap penduduk, penduduk non permanen dan penduduk sementara, mempunyai hak untuk memperoleh:

24 Soewarno Handayaningrat, Administrasi Pemarintahan dalam Pembangunan Nasional (Jakarta: Eka Parayangan, 1982), h. 154 
a. Dokumen kependudukan;

b. Pelayanan yang sama dalam pendaftaran penduduk dan pencatatan sipil;

c. Perlindungan atas data pribadi;

d. Kepastian hukum atas kepemilikan dokumen kependudukan;

e. Informasi mengenai data hasil pendaftaran penduduk dan pencatatan sipil atas dirinya dan/atau keluarganya; dan

f. Pemulihan nama baik sebagai akibat kesalahan dalam pendaftaran penduduk dan pencatatan sipil serta penyalahgunaan data pribadi oleh Instansi Pelaksana"

Jika kita mengacu pada Peraturan Daerah diatas dalam memberikan pelayanan, aparatur pelaksana seharusnya tidak diskriminatif, tidak mendahulukan individu yang memiliki kenalan/kerabat di lingkup Dinas Kependudukan dan Pencatatan Sipil Kota Palopo. Hal inilah yang akan menjadi penghambat untuk memperoleh akta kelahiran di Kota Palopo sebab pelayanan yang diberikan tidak prima.

Hal inilah yang disampaikan oleh Dea Citra Warga Jl. Libukang Permai, bahwa ia bukannya tidak mau mengurus akta kelahiran untuk anaknya, tetapi terdapat kendala yang membuat ia merasa malas jika harus berurusan dengan persoalan administrasi karena tidak mempunyai kenalan/kerabat yang bekerja di Dinas tersebut sehingga ia beranggapan bahwa proses pengurusannya akan lama. ${ }^{25}$ Apa yang disampaikan oleh Dea Citra merupakan pengalaman dari dirinya yang dirasakan secara langsung.

Untuk lebih memperkuat data yang lebih valid lagi maka penulis juga mengambil sampel dari sebahagian masyarakat dengan cara metode wawancara kepada masyarakat Kota Palopo selaku responden yang sedang mengurus dokumen kependudukan dalam hal ini akta kelahiran. Dari hasil wawancara yang dilakukan, penulis menemukan berbagai macam masalah yang dihadapi masyarakat dalam mengurus dokumen tersebut, mulai dari masalah prosedur pelayanan yang belum memuaskan karena terdapat tindakan diskriminatif dari aparatur pelaksana dan lain sebagainya. Kinerja dari aparat pelaksana pada Dinas Kependudukan dan Pencatatan Sipil Kota Palopo bisa disebut belum optimal dalam penyelenggaraannya. ${ }^{26}$

Secara normatif, berbagai peraturan yang mengatur mengenai pelayanan publik (public service) di Indonesia sangat baik. Namun secara implementasinya, pelayanan publik yang diselenggarakan oleh pusat maupun daerah nilai belumlah optimal. Belum optimalnya pelayanan publik memang bukanlah hal yang baru, faktanya Kinerja Dinas Kependudukan dan Pencatatan Sipil Kota Palopo tentang diskriminatif sudah menjadi rahasia umum didalam

${ }^{25}$ Wawancara Bersama Dea Citra Warga Jl. Libukang Permai, (31 Januari 2018)

26 Wawancara 10 Orang Masyarakat Kota Palopo Selaku Responden Pada Saat Pengurusan Dokumen Kependudukan Yang Berasal Dari sejumlah Kecamatan Yang Ada Di Kota Palopo (15 Februari 2018) 
pemerintahan. Tindakan diskriminatif ini dalam memberikan pelayanan amat dipengaruhi oleh hubungan kerabat.

Perilaku dari aparatur pelaksana ini pada umumnya di pengaruhi oleh dua hal yaitu faktor internal dan eksternal. Adapun faktor internal yang dimaksud adalah sumber daya manusia atau aparat pelaksananya yang dapat dilihat dari kualitas kerja pegawai, sikap pegawai yang kurang responsif terhadap masyarakat, kesadaran dan konsistensi dari aparat pelaksana dan sarana prasarana sebagai alat penunjang dalam pelayanan masyarakat. Sedangkan faktor eksternal itu meliputi seperti lokasi, lingkungan, masyrakat pelanggan jasa. Berdasarkan hasil pengamatan yang dilakukan faktor eksetrnal ini berasal dari masyarakat itu sendiri yang dalam pengurusannya terkadang menggunakan alasan mendesak sehingga masyarakat meminta percepatan proses pembuatan dokumennya.

Selain daripada itu terdapat juga pandangan sebagian masyarakat yang mengatakan bahwa kinerja para aparat pelaksana sudah optimal dalam memberikan pelayanan terhadap masyarakat dalam pengurusan dokumen kependudukannya karena sebahagian masyarakat berpendapat bahwa cepat atau lambat pengurusan dokumen kependudukan itu adalah prosedur yang ada di Dinas Kependudukan dan Cacatan Sipil Kota Palopo. Seperti yang disampaikan oleh Ibu Santi Warga Perumnas, yang secara pribadi sepanjang syarat yang diminta oleh Dinas Kependudukan Kota Palopo sudah lengkap ia hanya bisa menunggu, dia beranggapan cepat atau lambat setidaknya dia telah mengurus akta kelahiran untuk anaknya. ${ }^{27}$

Dalam konteks penyelenggaraan pelayanan publik, menurut Lenvine produk pelayanan publik dalam Negara demokrasi paling tidak harus memenuhi tiga indikator, yakni pertama, responsivitas adalah daya tanggap penyedia jasa terhadap harapan, keinginan, aspirasi maupun tuntutan pengguna layanan. Kedua, responsibilitas adalah suatu ukuran yang menunjukkan seberapa jauh proses pemberian layanan publik itu dilakukan sesuai dengan prinsip-prinsip atau ketentuanketentuan administrasi dan organisasi yang benar dan telah ditetapkan. Ketiga, akuntabilitas adalah suatu ukuran yang menunjukkan seberapa besar proses penyelenggaraan pelayanan sesuai dengan kepentingan stakeholders dan normanorma yang berkembang dalam masyarakat. ${ }^{28}$

\section{2) Sosialisasi Yang Tidak Merata}

Sosialisasi dapat diartikan sebagai proses dimana seseorang memperoleh pengetahuan, kemampuan dan dasar yang membuat mereka mampu atau tidak mampu menjadi anggota dari suatu kelompok. Pengertian ini memandang sosialisasi sebagai suatu proses belajar dimana individu belajar dan mendapatkan nilai dari kelompok-kelompok yang dimasukinya.

Dalam konteks tersebut kita melihat bahwa sosialisasi pada dasarnya bertujuan untuk memberikan pemahaman kepada individu atau kelompok.

\footnotetext{
${ }^{27}$ Wawancara Bersama Ibu Santi Warga Perumnas (31 Januari 2018)

${ }^{28}$ Sirajuddin, dkk., Hukum Pelayanan Publik, (Cet. 2; Malang: Setara Press, 2012), h. 41
} 
Sosialisasi sangat penting dilakukan karena dapat merangsang individu atau kelompok untuk bertindak dalam suatu hal berkenaan dengan tujuan yang ingin dicapai.

Salah satu upaya yang dilakukan oleh Dinas Kependudukan dan Pencatatan Sipil Kota Palopo dalam meningkatkan kepemilikan akta kelahiran bagi anak sudah dilakukan berdasarkan keterangan dari Sekertaris Dinas Kependudukan dan Pencatatan Sipil Kota Palopo. Namun demikian sosialisai yang dilakukan hanya sampai pada tingkat Kecamatan saja. Hal ini disampaikan oleh Ibu Dewi Warga di Kecamatan Bara, ia mengaku bahwa tidak mengetahui jika ada sosialisasi dari Dinas Kependudukan berkenaan dengan pentingnya akta kelahiran bagi anak. Kalau memang pernah ada berarti hanya dilakukan ditingkat atas tidak sampai ke semua lapisan masyarakat. ${ }^{29}$

Apa yang disampaikan oleh Ibu Dewi merupakan suatu penjelasan bahwa sosialisasi dari Dinas Kependudukan dan Pencatatan Sipil Kota Palopo memang haruslah sampai pada semua lapisan masyarakat, agar dapat memberikan pemahaman kepada masyarakat mengenai pentingya kepemilikan dokumen kependudukan dalam hal ini akta kelahiran bagi anak. Orang tua yang tidak mengetahui hal tersebut akan merugikan anak untuk memperoleh haknya dan juga identitas bagi anak tersebut. Dalam UU No. 23 Tentang Perlindungan Anak Pasal 27 berbunyi:

(1) Identitas diri setiap anak harus diberikan sejak kelahirannya.

(2) Identitas sebagaimana dimaksud dalam ayat (1) dituangkan dalam akta kelahiran.

(3) Pembuatan akta kelahiran didasarkan pada surat keterangan dari orang yang menyaksikan dan/atau membantu proses kelahiran

Berdasarkan Undang Undang diatas perlu ditekankan bahwa anak harus memiliki identitas yang dibuktikan dengan akta kelahiran. Tentunya agar mendapatkan akta kelahiran para orang tua harus memiliki pemahaman atau informasi tentang pentinya akta kelahiran yang dilakukan oleh Dinas Kependudukan dan Pencatatan Sipil Kota Palopo dalam hal ini melakukan sosialisasi yang merata.

\section{Faktor Penghambat dari Masyarakat}

Masyarakat menurut definisi para ahli secara umum, pengertian masyarakat adalah sekumpulan individu-individu yang hidup bersama. Istilah masyarakat berasal dari bahasa Arab dengan kata syarka. Syarka artinya ikut serta (berpartisipasi). Sedangkan dalam bahasa inggris masyarakat disebut dengan society yang pengertiannya adalah interaksi sosial, perubahan sosial dan rasa kebersamaan. Definisi lain masyarakat adalah kesatuan hidup manusia yang berinteraksi menurut suau sistem adat istiadat tertentu yang bersifat kontinu, dan yang terikat oleh suatu rasa identitas bersama. Kontinuitas merupakan kesatuan mayarakat yang memiliki keempat ciri yaitu

${ }^{29}$ Wawancara Bersama Ibu Dewi Warga Jl. Cengkeh (31 Januari 2018) 
Interaksi antara warga-warganya, Adat istiadat, kontinuitas waktu, rasa identitas kuat yang mengikat semua warga. ${ }^{30}$

Berbicara mengenai penegakkan hukum terhadap masyarakat sebenarnya memiliki tujuan untuk mencapai kedamaian dan ketentraman dimasyarakat, oleh karena itu dipandang dari sudut tertentu maka masyarakat dapat mempengaruhi penegakkan hukum. Dilihat dari sudut sosial budaya, masyarakat Kota Palopo sendiri memiliki tingkat partisipasi yang minim dalam penegakan peraturan yang berlaku dalam hal ini adalah peraturan Daerah Kota Palopo Nomor 8 Tahun 2013 Tentang Penyelenggaraan Administrasi Kependudukan. Setidaknya ada dua faktor yang membuat hambatan untuk memperoleh akta kelahiran bagi anak yang sumbernya berasal dari masyarakat yaitu kurangnya kesadaran bagi masyarakat dan tidak lengkapnya berkas yang diajukan.

\section{1) Kurangnya Kesadaran Masyarakat}

Kurangnya kesadaran masyarakat akan kepemilikan akta kelahiran bagi anak merupakan penunjang masalah dari masyarakat itu sendiri. Hal inilah yang peneliti temukan di lapangan bahwa kesadaran akan kepemilikan akta kelahiran sangatlah minim dan tentu akan berdampak pada anak dikemudian hari. Seperti yang disampaikan oleh Dea Citra warga di Jl. Libukang Permai, menurutnya memiliki akta kelahiran bukanlah hal yang penting karena akta kelahiran hanya dibutuhkan satu kali pada saat anaknya masuk Taman Kanak Kanak (TK) dan saat ini anaknya masih berumur 2 tahun sehingga dia baru akan mengurus akta kelahiran anaknya apabila nantinya akta tersebut memang diperlukan. ${ }^{31}$

Faktor kesadaran hukum masyarakat tidak dapat diabaikan begitu saja dalam menentukan sukses atau tidaknya penegakan suatu produk peraturan daerah, meskipun materi suatu peraturan daerah tersebut sudah baik dan telah dilengkapi oleh aparatur hukum yang cakap dalam menegakkannya, tanpa adanya budaya hukum yang kondusif di masyarakat rasanya akan sangat sulit bagi suatu produk peraturan perundangan dapat berjalan secara efektif. Sedangkan budaya hukum itu sendiri tercermin dalam sikap warga masyarakat yang sangat dipengaruhi oleh sistem yang dianut oleh masyarakat.

Dalam upaya mengefektivkan penerapan hukum, maka perlu dipahami pula kekuatan-kekuatan sosial yang melingkupinya. Karena sekalipun hukum itu nampak sebagai seperangkat norma-norma hukum, tetapi ia selalu merupakan hasil dari pada suatu proses sosial. Kekuatan-kekuatan sosial itu akan selalu berusaha untuk masuk dan mempengaruhi setiap proses pembentukan dan pelaksanaan hukum.

\section{2) Kelengkapan Berkas}

Dalam standar pelayanan minimum Dinas Kependudukan dan Pencatatan Sipil Kota Palopo Persyaratan pencatatan kelahiran penduduk

\footnotetext{
${ }^{30}$ Koentjaraningrat, Pengantar Ilmu Antropologi, (Jakarta: PT. Rineka Cipta, 2009), h. 115-118

${ }^{31}$ Wawancara Bersama Ibu Dea Citra Warga Jl. Libukang Permai (9 Februari 2018)
} 
WNI di daerah:

1. Surat Keterangan Kelahiran dari Kelurahan;

2. Asli dan Fotokopi Surat Keterangan Kelahiran dari dokter/bidan/penolong kelahiran/Nakhoda Kapal Laut atau Pilot Pesawat Terbang dengan memperlihatkan aslinya;

3. Fotokopi Surat Nikah/Akta Perkawinan orang tua;

4. Fotokopi KK dan KTP orang tua;

5. Nama dan identitas saksi pelaporan kelahiran;

6. Persetujuan Kepala Dinas dalam hal pelaporannya melebihi 60 (enam puluh) hari dan kurang dari 1 (satu) tahun sejak tanggal kelahirannya.

Dari syarat yang ditegaskan oleh Dinas Kependudukan dan Pencatatan Sipil Kota Palopo kelengkapan berkas oleh pemohon tidak sesuai seperti tidak memiliki buku nikah. Hal inilah yang disampaikan oleh Ibu Tenriawati,SH selaku sekertaris Dinas Kependudukan dan Pencatatan Sipil Kota Palopo, beliau mengatakan beberapa yang menjadi hambatan dalam penerbitan akta kelahiran salah satunya adalah tidak lengkapnya berkas yang diajukan oleh masyarakat salah satunya adalah kepemilikan buku nikah, kami di Dinas Kependudukan dan Pencatatan Sipil Kota Palopo kesulitan mencetak dokumen akta kelahiran jika orangtua tidak memiliki buku nikah sebab itu merupakan syarat yang paling penting dalam penerbitan akta kelahiran. ${ }^{32}$

Seperti yang disampaikan oleh Ibu Tenriawati,SH bahwa kelengkapan berkas sangatlah penting untuk diproses lebih lanjut lagi. Syarat-syarat yang telah ditentukan merupakan suatu keharusan yang harus dipenuhi oleh pemohon. Hal tersebut dibenarkan oleh Ibu Ema warga Kecamatan Telluwanua yang mengatakan bahwa sampai sekarang anaknya belum memiliki akta kelahiran karena terhambat dalam masalah kelengkapan berkas karena ia memang tidak memiliki buku nikah kerena beberapa hal dan sebab pada saat menikah, pernikahannya tidak terdaftar di Kantor Urusan Agama (KUA). ${ }^{33}$

\section{PENUTUP}

\section{Kesimpulan}

Berdasarkan hasil penelitian dan pokok masalah yang telah dibahas oleh penulis, maka dapat ditarik kesimpulan sebagai berikut:

1. Berdasarkan data dari Dinas Kependudukan dan Pencatatan Sipil Kota Palopo yang diperoleh oleh penulis dari tahun 2015-2017 ternyata banyak anak yang belum memiliki akta kelahiran di Kota Palopo. Hal ini menunjukkan peraturan Daerah Kota Palopo Nomor 8 Tahun 2013 Tentang Penyelenggaraan Administrasi Kependudukan tidak berjalan efektif sekalipun sudah ada aksi nyata yang dilakukan oleh Dinas Kependudukan Kota Palopo.

32 Wawancara Bersama Sekertaris Dinas Kependudukan Kota Palopo Ibu Tenriawati,SH, (2 Februari 2018)

${ }^{33}$ Wawancara Bersama Ibu Ema Warga di KecamatanTulluwanua (15 Februari 2018) 
2. Ada beberapa faktor yang ditemukan peneliti sehingga menjadi hambatan dalam penerbitan akta kelahiran bagi anak yaitu: Faktor penghambat dari penyelenggara pemerintah (aparat pelaksana) diantaranya adalah aparat pelaksana yang melakukan tindakan diskriminatif dan sosialisasi yang kurang merata. Adapun faktor penghambat yang berasal dari masyarakat yaitu kurangnya kesadaran masyarat mengenai pentingnya kepemilikan dokumen kependudukan dalam hal ini akta kelahiran dan tidak lengkapnya berkas yang diajukan masyarakat saat pengurusan akta kelahiran.

\section{Saran}

1. Diharapkan Dinas kependudukan dan catatan sipil kota Palopo terus meningkatkan serta mengoptimalkan pelayanannya secara merata dan keseluruhan, serta sosialisasi yang merata ke semua lapisan masyarat sehingga penyelenggaraan administrasi kependudukan dalam hal ini kepemilikan dokumen kependudukan yaitu akta kelahiran, bisa lebih efektif dan merata dalam berbagai tingkat kalangan dimasyarakat.

2. Diharapkan para aparatur pelaksana pemerintahan dan masyarakat saling bersinergi agar kepemilikan dokumen kependudukan khususnya kepemilikan akta kelahiran di Kota Palopo berjalan sesuai dengan yang diharapkan. Masyarakat haruslah patuh terhadap syarat mutlak yang diajukan oleh Dinas Kependudukan dan Pencatatan Sipil Kota Palopo dan Aparatur pelaksana pemerintahan harus memberikan pelayanan yang prima bagi masyarakat serta dalam melakukan sosialisasi mengenai kepemilikan dokumen kependudukan yang merata ke semua lapisan masyarakat agar Terwujudnya efektifitas pelaksanaan Peraturan Daerah Kota Palopo Nomor 8 Tahun 2013 tentang Penyelenggaraan Administrasi Kependudukan untuk memperoleh akta kelahiran bagi anak

\section{DAFTAR PUSTAKA}

Arief, Barda Nawawi, Beberapa Aspek Kebijakan Penegakan Dan Pengembangan Hukum Pidana, (Bandung: Citra Aditya Bakti, 1998)

Bungin, Burhan, Metodologi Penulisan Kualitatif, (Jakarta: Kencana, 2009)

Departemen Pendidikan Nasional, Kamus Besar Bahasa Indonesia (Cet. 3. Jakarta: Balai Pustaka, 2005)

Eddyono, Supriyadi W., Pengantar Konvensi Hak Anak, (Jakarta: ELSAM, 2005)

Gultom, Maidin, Perlindungan Hukum Terhadap Anak dan Perempuan, (Bandung: PT Refika Aditama, 2012)

Gultom, Maidin, Perlindungan Hukum Terhadap Anak Dalam Sistem Peradilan Pidana Anak di Indonesia, (Bandung: Refika Aditama, 2010)

Gosita, Arif, Masalah Perlindungan Anak, (Jakarta: Akademi Pressindo, 1989) 
Handayaningrat, Soewarno, Administrasi Pemarintahan dalam Pembangunan Nasional, (Jakarta: Eka Parayangan, 1982)

HS, H, Halim, Nurbayani, Erlies, Septian, dalam Koentjaraningrat, Penerapan Teori Hukum pada Penelitian Tesis dan Disertasi, (Raja Grafindo Persada: Jakarta, 2014)

Idrus, Muhammad, Metode Penelitian Ilmu Sosial Pendekatan Kualitatif dan Kuantitatif, (Jakarta: Erlangga, 2011)

Ilyas, Yunahar, Kuliah Akhlak, (Yogyakarta: LPPI Universitas Muhammadiyah Yogyakarta, 2007)

Kamello, Tan, dkk, Hukum Perdata Hukum Orang dan Keluarga, (Medan: USU Press, 2011)

Kountur, Ronny, Metode Penelitian Untuk Penulisan Skripsi dan Tesis, (Jakarta: PPM, 2004)

Koentjaraningrat, Pengantar Ilmu Antropologi, (Jakarta: PT. Rineka Cipta, 2009)

Mulyadi, Lilik, Pengadilan Anak di Indonesia Teori Praktek dan Permasalahannya, (Bandung : CV. Mandar Maju, 2005)

Prawirohamidjojo, R. Soetojo dan Marthalena Pohan, Hukum Orang dan Keluarga (Personen en Familie Recht), (Surabaya: Airlangga University Press, 2000)

Prints, Darwan, Hukum Anak Indonesia, (Bandung: PT. Citra Aditya Bakti, 2003)

Puspitosari, Hesti, dkk, Filosofi Pelayanan Publik, (Malang: Setara Press, 2012)

Siswosoediro, Henry S., Mengurus Surat-Surat Kependudukan (Identitas Diri), (Jakarta: Visimedia, 2008)

Sirajuddin, dkk., Hukum Pelayanan Publik, (Cet. 2; Malang: Setara Press, 2012)

Soekanto, Soerjono, Pengantar Penelitian Hukum, (Cet. 3, Jakarta: PT Universitas Indonesia, 2010)

Soekanto, Soerjono, Pokok-Pokok Sosiologi Hukum, (Jakarta: Raja Grafindo Persada, 2007)

Soerjono, dan Abdurrahman, Bentuk Penelitian Suatu Pemikiran dan Penerapan, (Jakarta: Rineka Cipta, 1991)

Sugiyono, Metode Penelitian Kuantitatif, Kualitatif dan RED, (Bandung: CV. Alfabeta, 2009)

Syahrani, Riduan, Seluk Beluk dan Asas-Asas Hukum Perdata, (Bandung, PT. Alumni, 1993)

Widagdo, Setiawan, Kamus Hukum, (Jakarta: Prestasi Pustaka, 2012)

\section{Undang-undang}

Undang-Undang Nomor 39 Tahun 1999 tentang Hak Asasi Manusia Undang-Undang Nomor 23 tahun 2002 tentang Perlindungan Anak Undang-Undang Nomor 4 Tahun 1979 tentang Kesejahteraan Anak Undang-Undang Nomor 23 Tahun 2006 tentang Administrasi Kependudukan Peraturan Daerah Kota Palopo Nomor 8 Tahun 2013 tentang Penyelenggaraan Administrasi Kependudukan 


\section{Website}

http://www.palopokota.go.id/blog/page/geografis Diakses Pada Tanggal 4 Februari 2018 